\title{
Hubungan Persepsi Peserta Didik Tentang Pola Asuh Orang Tua, Kebiasaan Belajar dengan Hasil Belajar
}

\author{
Nur Kholifah, Supriyadi, Suwarjo \\ Pendidikan Guru Sekolah Dasar, Universitas Lampung \\ Jln. Prof. Dr. Soemantri Brojonegoro No. 1 Bandar Lampung 45145 \\ E-mail: nurk5440@gmail.com
}

\section{Article Info}

Received December 2018

Accepted Februari 2019

Published April 2019

Keywords:

learning achievement, study habits,

parenting parents

\section{Abstract}

The purpose of this research was to find out the significant and positive correlation between student perception about parenting parents and learning achievement, learning habits and learning achievement, and student perception about parenting parents and learning habits together with learning achievement thematic of fourth grade students SD Muhammadiyah Metro Central. The type of research was ex-postfacto correlation. Population was 230 and sample was 70 students. Data collection techniques used observation, questionnaire and documentation studies. Data analysis technique used was product moment correlation and multiple correlation. The results showed that there was a significant and positive correlation between student perception about parenting parents and learning achievement indicated at "low" level, there was a significant and positive correlation between learning habits and learning achievement indicated at "low" level, and there was a significant and positive correlation between student perception about parenting parents and learning habits together with learning achievement indicated at "moderate" level.

\begin{abstract}
Abstrak : Penelitian ini bertujuan untuk mengetahui hubungan yang signifikan dan positif antara persepsi peserta didik tentang pola asuh orang tua dengan hasil belajar, kebiasaan belajar dengan hasil belajar, serta persepsi peserta didik tentang pola asuh orang tua dan kebiasaan belajar secara bersama-sama dengan hasil belajar tematik peserta didik kelas IV SD Muhammadiyah Metro Pusat. Metode penelitian yaitu ex-postfacto korelasi. Populasi berjumlah 230 dan sampel penelitian berjumlah 70 orang. Teknik pengumpulan data yaitu: observasi, kuesioner (angket), dan studi dokumentasi. Analisis data yang digunakan adalah korelasi product moment dan multiple correlation. Hasil penelitian, diperoleh bahwa terdapat hubungan yang signifikan dan positif antara persepsi peserta didik tentang pola asuh orang tua dengan hasil belajar ditunjukan dengan taraf "rendah", terdapat hubungan yang signifikan dan positif antara kebiasaan belajar dengan hasil belajar ditunjukan dengan taraf "rendah", dan terdapat hubungan yang signifikan dan positif antara persepsi peserta didik tentang pola asuh orang tua dan kebiasaan belajar secara bersama-sama dengan hasil belajar ditunjukan dengan taraf "sedang".
\end{abstract}

Kata kunci: hasil belajar, kebiasaan belajar, pola asuh orang tua

(C2019 Jurusan Ilmu Pendidikan, FKIP Universitas Lampung p-ISSN (Media Cetak) 2656-8527 


\section{PENDAHULUAN}

Pendidikan merupakan hal yang penting bagi kehidupan manusia. Pendidikan menjadikan seseorang lebih bertakwa kepada Tuhan Yang Maha Esa, memiliki keterampilan, pengetahuan dan kepribadian yang akan mengembangkan potensi diri yang dimiliki serta turut berperan terhadap kemajuan bangsa. Keberhasilan pembangunan suatu bangsa ditentukan oleh kualitas pendidikan bangsa tersebut. Salah satu usaha yang dilakukan pemerintah untuk mewujudkan hal tersebut adalah dengan meningkatkan kualitas pendidikan dimulai dari jenjang sekolah dasar.

Keberhasilan dalam proses pembelajaran di sekolah dapat dilihat dari hasil belajar yang dicapai oleh peserta didik. Hasil belajar sering kali digunakan sebagai ukuran untuk mengetahui seberapa jauh seseorang menguasai bahan yang sudah diajarkan. Sudjana (2010) menyatakan bahwa hasil belajar peserta didik pada hakikatnya adalah perubahan tingkah laku sebagai hasil belajar dalam pengertian yang lebih luas mencakup bidang kognitif, afektif, dan psikomotor sebagai hasil dari belajar.

Tinggi rendahnya hasil belajar dipengaruhi oleh beberapa faktor. Wasliman (dalam Susanto, 2013) berpendapat bahwa hasil belajar yang dicapai oleh peserta didik merupakan hasil interaksi antara berbagai faktor yang mempengaruhi, baik faktor internal maupun eksternal. Uraian mengenai faktor internal dan eksternal sebagai berikut. (1) faktor internal; merupakan faktor yang bersumber dari dalam diri peserta didik, yang mempengaruhi kemampuan belajarnya, meliputi: kecerdasan, minat dan perhatian, motivasi belajar, serta kondisi fisik dan kesehatan. (2) faktor eksternal; merupakan faktor yang berasal dari luar peserta didik yang mempengaruhi hasil belajar yaitu keluarga, sekolah dan masyarakat.

Pola asuh keluarga termasuk ke dalam salah satu faktor keluarga yang dapat mempengaruhi pencapaian hasil belajar seorang peserta didik. Steinberg (dalam Spera, 2010) "define a parenting style as the emotional climate in which parents raise their children" (mendefinisikan gaya pengasuhan sebagai iklim emosional di mana orang tua membesarkan anak-anak mereka). Hasil penelitian nya menunjukan bahwa orang tua memiliki pengaruh yang 
signifikan terhadap prestasi sekolah anak-anak mereka, dengan dugaan bahwa ketika orang tua terlibat dalam pendidikan anak mereka dan memantau kegiatan anak-anak mereka disekolah, mereka akan memfasilitasi prestasi akademik dan pencapaian pendidikan anak-anak mereka.

Pola asuh orang tua yang diterima oleh setiap peserta didik sangatlah beragam, hal ini tergantung dari cara pola asuh keluarga yang diterapkan oleh orang tua kepada anaknya. Hurlock (dalam Karnangsyah, 2017) membagi gaya pengasuhan orangtua menjadi 3 : (a) authoritative parenting (demokratis), (b) authoritarian parenting (otoriter), dan (c) permissive parenting (permisif). Setiap masing-masing pola asuh orang tua tersebut memiliki karakter yang berbeda-beda. Orang tua hendaknya memikirkan kondisi anak untuk mempertimbangkan cara-cara mendidik anak, sehingga kemudian dapat memutuskan dengan tepat jenis pola asuh yang akan diterapkan terhadap anak. Secara umum peserta didik yang memperoleh pola asuh yang baik dari kedua orang tuanya, cenderung memiliki kebiasaan-kebiasan atau pola tingkah laku yang baik dalam kehidupan kesehariannya di lingkungan keluarga, sekolah maupun lingkungan masyarakat.

Perbedaan pola asuh keluarga secara tidak langsung akan mempengaruhi kebiasaan-kebiasaan anak, baik di rumah maupun di sekolah. Orang tua yang membiasakan anak untuk selalu belajar di rumah akan membuat anak memiliki kebiasaan belajar yang baik dan berpengaruh terhadap hasil belajar anak. Sesuai yang diungkapkan oleh Surya (dalam Garliah, 2010) "bimbingan atau pola asuh orang tua berperan untuk mengembangkan potensi diri anak melalui pola-pola kebiasaan yang dilakukannya sehari-hari, baik di lingkungan sekolah, keluarga dan masyarakat".

Kebiasaan belajar berhubungan positif dengan hasil belajar, yaitu semakin baik kebiasaan belajar peserta didik akan semakin baik nilai hasil belajarnya. Maghfirah (2015) menyampaikan kebiasaan belajar dapat diartikan sebagai cara atau teknik yang menetap pada diri peserta didik pada waktu menerima pelajaran, membaca buku, mengerjakan tugas, dan pengaturan waktu untuk menyelesaikan kegiatan. Peserta didik yang memiliki kebiasaan belajar 
yang baik maka hasil belajar yang dicapai akan maksimal dan begitupun sebaliknya.

Kebiasaan terbentuk melalui enam tahapan yang diungkapkan oleh Elfiky (dalam Siagian, 2014) mengemukakan bahwa, "kebiasaan terbentuk melalui enam tahapan yaitu befikir, perekaman, pengulangan, penyimpanan, pengulangan, dan kebiasaan". Dalam penjelasanya lebih lanjut Elfiky menjelaskan, dalam tahapan berfikir seseorang memikirkan sesuatu, memberi perhatian, dan berkonsentrasi padanya. Selanjutnya, tahap perekaman adalah ketika seseorang memikirkan sesuatu dan otaknya merekam. Dalam tahap pengulangan, seseorang memutuskan untuk mengulang perilaku yang sama dengan perasaan yang sama. Setelah mengulang, seseorang akan menyimpannya dalam file dan menghadirkanya setiap kali menghadapi kondisi serupa. Terakhir tahap pengulangan, dalam tahap ini, disadari atau tidak, seseorang mengulang kembali perilaku yang tersimpan kuat di dalam akal bawah sadarnya.

Anak yang memiliki kebiasaan belajar yang baik akan membuat anak mencapai hasil belajar yang maksimal. Hasil Penelitian dari Hidayati (2016) menunjukan bahwa kebiasaan belajar peserta didik mempengaruhi hasil belajar yang dicapai. Semakin baik kebiasaan belajar peserta didik maka semakin baik pula hasil belajarnya begitupun sebaliknya.

Pada kenyataannya, dari hasil observasi dan wawancara yang telah dilakukan oleh peneliti dengan pendidik kelas IV SD Muhammadiyah Metro Pusat, didapatkan informasi bahwa masih ada peserta didik yang kurang mendapat perhatian dari orang tuanya. Hal ini dapat dilihat dari masih adanya orang tua yang kurang peduli dengan urusan sekolah anak, seperti kurang penyediaan fasilitas belajar anak, kerapian anak dalam berpakaian, sering terlambat berangkat sekolah, tidak mengerjakan PR dan lain sebagainya.

Selain dari segi pola asuh orang tua, kebiasaan belajar peserta didik juga masih perlu diperbaiki. Masih ada beberapa peserta didik yang kurang dalam membaca buku dan membuat catatan, tidak fokus memperhatikan penjelasan pendidik ketika belajar di kelas, tidak mengerjakan tugas dengan baik, dan tidak memiliki jadwal belajar yang pasti di rumah. 
Hasil observasi dan studi dokumentasi yang dilakukan peneliti diperoleh data bahwa masih ada peserta didik yang memiliki hasil belajar yang belum optimal. Data yang dimaksud peneliti adalah persentase ketuntasan nilai uangan harian semester ganjil Tema 1 Subtema 1 (Indahnya Kebersamaan) peserta didik kelas IV SD Muhammadiyah Metro Pusat sebagai berikut:

Tabel 1. Nilai ulangan harian semester ganjil kelas IV

Tahun pelajaran 2018/2019

\begin{tabular}{|c|l|c|c|c|c|c|}
\hline \multirow{2}{*}{ No } & \multirow{2}{*}{ Kelas } & \multicolumn{4}{|c|}{ Ketuntasan } & \multirow{2}{*}{$\Sigma$} \\
\cline { 3 - 6 } & & \multicolumn{2}{|c|}{ Tuntas $(\geq 80)$} & \multicolumn{2}{c|}{ Belum tuntas $(<80)$} & \multirow{2}{*}{$\Sigma$} \\
\cline { 3 - 6 } & & Angka & Persentase & Angka & Persentase & \\
\hline 1 & IV Harun AS & 14 & 44 & 18 & 56 & 32 \\
\hline 2 & IV Zulkifli AS & 14 & 45 & 17 & 55 & 31 \\
\hline 3 & IV Daud AS & 16 & 47 & 18 & 53 & 34 \\
\hline 4 & IV SulaimanAS & 15 & 45 & 18 & 55 & 33 \\
\hline 5 & IV Ilyas AS & 15 & 44 & 19 & 56 & 34 \\
\hline 6 & IV Ilyasa AS & 16 & 48 & 17 & 52 & 33 \\
\hline 7 & IV Yunus AS & 16 & 48 & 17 & 52 & 33 \\
\hline \multicolumn{2}{|l|}{ Jumlah Peserta didik } & 106 & - & 124 & - & 230 \\
\hline
\end{tabular}

Sumber: Dokumentasi pendidik kelas IV SD Muhammadiyah Metro Pusat.

Berdasarkan tabel tersebut dapat dilihat bahwa ada 124 peserta didik atau $54 \%$ yang belum tuntas atau nilainya tidak memenuhi standar KKM yaitu 80. Pemaparan tersebut memungkinkan bahwa pola asuh yang diterapkan oleh orang tua dan kebiasaan belajar anak mempengaruhi hasil belajar yang dicapai oleh peserta didik. Karena setiap orang tua yang satu dengan yang lain memberikan pola asuh yang berbeda dalam membimbing dan mendidik anakanaknya. Salah satu cara terbaik untuk mengetahui pola asuh yang diterapkan tersebut adalah melalui penilaian atau persepsi anak terhadap kebiasaankebiasaan dan sikap orang tua dalam mengasuh anaknya. Penelitian ini bertujuan untuk mengetahui hubungan persepsi peserta didik tentang pola asuh orang tua dan kebiasaan belajar dengan hasil belajar tema 1 subtema 1 (Indahnya Kebersamaan) peserta didik kelas IV SD Muhammadiyah Metro Pusat. 


\section{METODE}

Jenis penelitian ini adalah penelitian kuantitatif. Peneliti menggunakan metode penelitian ex post facto korelasi. Sugiyono dalam Riduwan (2013) mengemukakan penelitian ex post facto kolerasi adalah suatu penelitian yang dilakukan untuk meneliti peristiwa yang telah terjadi dan kemudian melihat ke belakang untuk mengetahui faktor-faktor yang dapat menimbulkan kejadian tersebut. Penelitian ini bertujuan untuk mengetahui hubungan persepsi peserta didik tentang pola asuh orang tua dan kebiasaan belajar dengan hasil belajar tematik peserta didik kelas IV SD Muhammadiyah Metro Pusat.

Penelitian ini dilaksanakan di SD Muhammadiyah Metro Pusat, Kelurahan Imopuro, Kecamatan Metro Pusat, Kota Metro Provinsi Lampung. Penelitian ini dilaksanakan pada semester ganjil tahun pelajaran 2018/2019.

Prosedur pada penelitian ini adalah sebagai berikut; (1) Memilih subjek penelitian yaitu peserta didik kelas IV SD Muhammadiyah Metro Pusat. Subjek uji coba instrumen kuesioner (angket) yaitu 30 orang peserta didik yang merupakan bagian dari subjek penelitian namun tidal termasuk dalam sampel penelitian. (2) Menyusun kisi-kisi dan instrumen pengumpulan data berupa angket. (3) Menguji coba instrumen. (4) Menaganalisis data dari hasil uji coba instrumen untuk mengetahui apakah instrumen yang telah dibuat valid dan reliabel. (5) Melaksanakan penelitian dengan membagikan instrumen angket kepada sampel penelitian. Selanjutnya untuk mengetahui hasil belajar peserta didik peneliti menggunakan studi dokumentasi yang dilihat pada dokumen hasil ulangan harian dari pendidik kelas IV SD Muhammadiyah Metro Pusat. (6) Menghitung ketiga data yang diperoleh untuk mengetahui hubungan dan tingkat keterkaitan persepsi peserta didik tentang pola asuh orang tua dan kebiasaan belajar dengan hasil belajar tema 1 subtema 1 (Indahnya Kebersamaan) peserta didik kelas IV SD Muhammadiyah Metro Pusat. (7) Interpretasi hasil penghitungan data.

Teknik analisis data untuk menguji hipotesis menggunakan rumus Korelasi Product Moment dan Multiple Correlation, dengan data yang diperoleh melalui angket dan studi dokumentasi berupa nilai ulangan harian semester ganjil kelas IV SD Muhammadiyah Metro Pusat. Sebelum 
dilaksanakan analisis data, terlebih dahulu peneliti harus melakukan pungujian prasyarat analisis dengan menguji normalitas dan linearitas data.

Uji hipotesis menggunakan rumus korelasi Product Moment, Multiple Correlation dan uji-F, sedangkan menentukan besar kecilnya kontribusi variabel $\mathrm{X}_{1}$ (persepsi peserta didik tentang pola asuh orang tua) dan variabel $\mathrm{X}_{2}$ (kebiasaan belajar) dengan $\mathrm{Y}$ (hasil belajar) dengan rumus koefisien determinan.

Sedangkan signifikansi hubungan dilihat dari hasil perhitungan uji-F dengan kaidah: jika $F_{\text {hitung }}>F_{\text {tabel, }}$ artinya terdapat hubungan yang signifikan atau hipotesis penelitian diterima. Sedangkan jika $t_{\text {hitung }}<t_{\text {tabel }}$, artinya tidak terdapat hubungan yang signifikan atau hipotesis penelitian ditolak.

\section{HASIL DAN PEMBAHASAN}

\section{Hasil Penelitian}

Berdasarkan hasil penelitian dan studi dokumentasi yang dilaksanakan pada peserta didik kelas IV SD Muhammadiyah Metro Pusat, diperoleh data sebagai

berikut:

Tabel 1. Deskripsi variabel Y

\begin{tabular}{llll}
\hline No. & Nilai & Kategori & Frekuensi \\
\hline 1 & $<80$ & Belum tuntas & 21 \\
\hline 2 & $\geq 80$ & Tuntas & 49 \\
\hline Jumlah & & 70 \\
\hline
\end{tabular}

Berdasarkan data di atas, Terlihat hanya 21 orang peserta didik yang belum tuntas, selanjutnya 49 orang peserta didik sudah mencapai kategori tuntas dari KKM yang ditentukan yaitu sebesar 80 . 
Tabel 2. Deskripsi variabel $\mathrm{X}_{1}$

\begin{tabular}{cccc}
\hline No. & Interval & F & Frekuensi (\%) \\
\hline $\mathbf{1}$ & $39-42$ & 5 & $7,14 \%$ \\
\hline $\mathbf{2}$ & $43-46$ & 7 & $10 \%$ \\
\hline $\mathbf{3}$ & $47-50$ & 9 & $12,86 \%$ \\
\hline $\mathbf{4}$ & $51-54$ & 18 & $25,71 \%$ \\
\hline $\mathbf{5}$ & $55-58$ & 12 & $17,14 \%$ \\
\hline $\mathbf{6}$ & $59-62$ & 10 & $14,29 \%$ \\
\hline $\mathbf{7}$ & $63-66$ & 9 & $12,86 \%$ \\
\hline & Jumlah & 70 & \\
\end{tabular}

Data di atas menunjukkan bahwa frekuensi tertinggi terdapat pada kelas interval 51 - 54 yakni sebanyak 18 orang peserta didik, sedangkan terendah terdapat pada kelas interval 39 - 42 sebanyak 5 orang peserta didik.

Tabel 3. Deskripsi variabel $\mathrm{X}_{2}$

\begin{tabular}{cccc}
\hline No & Kelas Interval & F & Frekuensi (\%) \\
\hline $\mathbf{1}$ & $44-48$ & 4 & $5,71 \%$ \\
\hline $\mathbf{2}$ & $49-53$ & 7 & $10 \%$ \\
\hline $\mathbf{3}$ & $54-58$ & 17 & $21,51 \%$ \\
\hline $\mathbf{4}$ & $59-63$ & 19 & $27,14 \%$ \\
\hline $\mathbf{5}$ & $64-68$ & 16 & $22,85 \%$ \\
\hline $\mathbf{6}$ & $69-73$ & 4 & $5,71 \%$ \\
\hline $\mathbf{7}$ & $74-78$ & 3 & $4,28 \%$ \\
\hline & Jumlah & 70 & \\
\hline
\end{tabular}

Berdasarkan data di atas menunjukkan bahwa frekuensi tertinggi terdapat pada kelas interval 59 - 63 yakni sebanyak 19 orang peserta didik, sedangkan terendah terdapat pada kelas interval 44 - 48 sebanyak 4 orang, 69 - 73 sebanyak 4 orang peserta didik, dan $74-78$ sebanyak 3 orang peserta didik. 


\section{Uji Normalitas}

Hasil perhitungan uji normalitas variabel $X_{1}$ didapati $\chi^{2}$ hitung $=6,841 \leq X_{\text {tabel }}^{2}=$ 12,592 berarti data variabel $X_{1}$ berdistribusi normal. Sedangkan hasil uji normalitas pada variabel $X_{2}$ didapati $\chi^{2}$ hitung $=2,881 \leq X_{\text {tabel }}^{2}=12,592$ berarti data variabel $X_{2}$ berdistribusi normal, dan uji normalitas pada variabel $\mathrm{Y}$ didapati bahwa $X^{2}{ }_{\text {hitung }}=$ $4,920 \leq X_{\text {tabel }}^{2}=12,592$ berarti data variabel Y berdistribusi normal

\section{Uji Linearitas}

Hasil dari uji linearitas dari variabel $\mathrm{X}_{1}$ dan variabel $\mathrm{Y}$ didapati bahwa $\mathrm{F}_{\text {hitung }}$ $=1,07 \leq \mathrm{F}_{\text {tabel }}=1,81$ hal ini berarti data berpola linier. Sedangkan hasil uji linieritas dari variabel $\mathrm{X}_{2}$ dan variabel $\mathrm{Y}$ didapati bahwa $\mathrm{F}_{\text {hitung }}=1,37 \leq \mathrm{F}_{\text {tabel }}=1,74$ hal ini berarti data berpola linier.

\section{Uji Hipotesis}

Berdasarkan hasil perhitungan uji hipotesis, ternyata koofisien korelasi antara variabel $\mathrm{X}_{1}$ dan variabel $\mathrm{Y}$ sebesar 0,389 itu berarti korelasi tersebut bertanda positif dengan kriteria rendah. Koofisien korelasi antara variabel $\mathrm{X}_{2}$ dan variabel $\mathrm{Y}$ sebesar 0,238 itu berarti korelasi tersebut bertanda positif dengan kriteria rendah. Koofisien korelasi antara variabel $\mathrm{X}_{1}$ dan $\mathrm{X}_{2}$ bersama-sama variabel $\mathrm{Y}$ sebesar 0,436 itu berarti korelasi tersebut bertanda positif dengan kriteria sedang.

Selanjutnya kontribusi variabel $\mathrm{X}_{1}$ dan $\mathrm{X}_{2}$ terhadap variabel $\mathrm{Y}$ sebesar $19,00 \%$. Hal ini berarti persepsi peserta didik tentang pola asuh orang tua dan kebiasaan belajar memberi pengaruh sebesar 19,00\% terhadap hasil belajar peserta didik kelas IV SD Mhammadiyah Metro Pusat. Sedangkan sisanya 81,00\% dipengaruhi oleh faktor-faktor lain seperti: kecerdasan, minat, motivasi belajar, ketekunan sikap, serta faktor eksternal meliputi sekolah, keluarga dan masyarakat.

Nilai kebermaknaan (signifikan) sebesar $\mathrm{F}_{\text {hitung }}=3,43>\mathrm{F}_{\text {tabel }}=3,13$ berarti signifikan. Hal ini berarti hipotesis diterima, , terdapat hubungan yang positif dan signifikan antara persepsi peserta didik tentang pola asuh orang tua dan kebiasaan belajar dengan hasil belajar tema 1 subtema 1 (Indahnya Kebersamaan) peserta didik kelas IV SD Muhammadiyah Metro Pusat. 


\section{Pembahasan}

Berdasarkan hasil perhitungan uji hipotesis di atas, ternyata koefisien korelasi antara variabel $\mathrm{X}_{1}$ dan variabel $\mathrm{Y}$ sebesar 0,389 itu berarti korelasi tersebut bertanda positif dengan kriteria rendah. Selanjutnya diketahui bahwa kontribusi varibel $\mathrm{X}_{1}$ terhadap variabel Y sebesar $15,13 \%$. Hal itu berarti persepsi peserta didik tentang pola asuh orang tua memberi pengaruh sebesar $15,13 \%$ dengan hasil belajar tema 1 subtema 1 (Indahnya Kebersamaan) peserta didik kelas IV SD Muhammadiyah Metro Pusat. Dengan demikian, terdapat hubungan yang signifikan dan positif antara persepsi peserta didik tentang pola asuh orang tua dengan hasil belajar tema 1 subtema 1 (Indahnya Kebersamaan) peserta didik kelas IV SD Muhammadiyah Metro Pusat. Hal ini relevan dengan penelitian Oktarina (2010) yang menyatakan bahwa terdapat hubungan yang signifikan dan positif antara persepsi peserta didik tentang pola asuh orang tua dengan prestasi belajar peserta didik.

Pada kehidupan anak selama berada dirumah yang paling bertanggung jawab akan perkembangan anak adalah orang tua. Hurlock (dalam Karnangsyah, 2017) menyatakan bahwa orang tua yang satu dan yang lainnya memberikan pola asuh yang berbeda dalam membimbing dan medidik anak-anaknya. Dari latar belakang keluarga yang berbeda akan membentuk pola asuh orang tua yang berbeda-beda dan perbedaan pola pengasuhan itu mempengaruhi hasil belajar anak. Sifat orang tua terhadap anak, praktik pengelolan keluarga, ketegangan dalam keluarga, semua yang terjadi pada anak dapat memberi dampak baik maupun buruk terhadap kegiatan belajar anak. Oleh karena itu orang tua perlu menerapkan pola pengasuhan yang tepat untuk membuat anak maksimal dalam mencapai hasil belajar.

Orang tua yang menerapkan pola pengasuhan yang tepat akan menciptakan tingkah laku baik pada anak dalam belajar dan mampu memaksimalkan hasil belajar yang dicapai. Orang tua yang menerapkan pola asuh yang kurang tepat membuat pola tingkah laku yang anak yang kurang baik dan juga akan berdampak anak kurang maksimal dalam mencapai hasil belajar. Hal tersebut sesuai dengan hipotesis yang diajukan yaitu terdapat hubungan yang signifikan dan positif antara persepsi peserta didik tentang pola asuh orang tua dengan hasil belajar tema 1 subtema 1 (Indahnya Kebersamaan) peserta didik kelas IV SD Muhammadiyah Metro Pusat. Hubungan ini ditandai dengan koefisien korelasi sebesar 0,389 pada taraf rendah dan sumbangan 
variabel X1 terhadap Y sebesar 15,13\% dan 84,87\% dipengaruhi oleh faktor lain seperti: intelegensi, minat dan motivasi belajar, bakat, dan faktor dari sekolah serta masyarakat.

Berdasarkan hasil perhitungan uji hipotesis kedua, ternyata koefisien korelasi antara variabel $\mathrm{X}_{2}$ dan variabel $\mathrm{Y}$ sebesar 0,238 itu berarti korelasi tersebut bertanda positif dengan kriteria rendah (dapat dilihat pada tabel 6 hal 61). Selanjutnya diketahui bahwa kontribusi varibel $\mathrm{X}_{2}$ terhadap variabel $\mathrm{Y}$ sebesar 5,66\%. Hal itu berarti kebiasaan belajar peserta didik memberi pengaruh sebesar 5,66 \% terhadap hasil belajar peserta didik kelas IV SD Muhammadiyah Metro Pusat. Dengan demikian, terdapat hubungan yang signifikan dan positif antara kebiasaan belajar dengan hasil belajar tema 1 subtema 1 (Indahnya Kebersamaan) peserta didik kelas IV SD Muhammadiyah metro pusat. Hal ini relevan dengan penelitian Siagian (2014) yang menyatakan bahwa terdapat hubungan yang signifikan dan positif antara kebiasaan belajar dengan prestasi belajar peserta didik.

Peserta didik memerlukan suatu pembiasaan yang baik dalam belajar yang disebut dengan kebiasaan belajar untuk mendukung peserta didik dalam mencapai hasil yang baik dalam pembelajaran. Baiknya hasil belajar dipengaruhi oleh banyak faktor salah satunya kebiasaan belajar. Aunurrahman (2013) menjelaskan kebiasaan belajar adalah perilaku seseorang yang telah tertanam dalam waktu yang relatif lama sehingga memberikan ciri dalam aktivitas belajar yang dilakukannya.

Kebiasaan belajar yang baik tentunya akan berdampak terhadap hasil belajar yang optimal. Sagala (2010) menyatakan secara umum salah satu kebiasaan belajar yang baik dapat dideskripsikan dengan belajar yang efisien yang ditampakkan pada komitmen yang tinggi untuk memanfaatkan waktu yang telah diatur. Pembentukan kebiasaan belajar yang baik ditentukan dari pengelolaan waktu yang tepat. Ketika anak memiliki kebiasaan belajar yang baik di rumah maupun di sekolah akan membuat anak mencapai hasil belajar yang maksimal, dan jika anak tidak memiliki pembiasaan belajar yang baik, tentunya anak akan malas belajar dan berdampak negatif pada proses pembelajaran dan akhirnya tidak dapat memaksimalkan hasil belajarnya.

Berdasarkan uraian di atas maka peneliti menyimpulkan bahwa hipotesis diterima artinya ada hubungan yang signifikan dan positif antara kebiasaan belajar 
dengan hasil belajar tema 1 subtema 1 (Indahnya Kebersamaan) peserta didik kelas IV SD Muhammadiyah Metro Pusat. Hubungan ini ditandai dengan koefisien korelasi sebesar 0,238 pada taraf rendah dan sumbangan variabel $\mathrm{X}_{2}$ terhadap $\mathrm{Y}$ sebesar 5,66\% dan 94,34\% dipengaruhi oleh faktor lain, seperti intelegensi, minat dan motivasi belajar, bakat, serta faktor eksternal lainnya meliputi keluarga, masyarakat dan sekolah.

Berdasarkan hasil perhitungan uji hipotesis di atas, diperoleh hasil koofisien korelasi antara $X_{1}$ dan $X_{2}$ secara bersama-sama dengan variabel $Y$ sebesar 0,436 bertanda positif dengan kriteria sedang (dapat dilihat pada tabel 6 hal 61). Kontribusi variabel $\mathrm{X}_{1}$ dan $\mathrm{X}_{2}$ terhadap variabel $\mathrm{Y}$ sebesar 19,00\%. Hal itu berarti persepsis peserta didik tentang pola asuh orang tua dan kebiasaan belajar secara bersama-sama memberi pengaruh sebesar $19,00 \%$ terhadap hasil belajar tema 1 subtema 1 (Indahnya Kebersamaan) siwa kelas IV SD Muhammadiyah Metro Pusat. Dengan demikian, terdapat hubungan yang signifikan antara persepsi peserta didik tentang pola asuh orang tua dan kebiasaan belajar dengan hasil belajar tema 1 subtema 1 (Indahnya Kebersamaan) peserta didik kelas IV SD Muhammadiyah Metro Pusat.

Ketika belajar setiap peserta didik mempunyai kebiasan yang berbeda-beda. Kebiasaan dalam belajar akan menunjang hasil belajar dari peserta didik itu sendiri. Guna mencapai hasil belajar perlu mengetahui dan memahami cara-cara belajar yang baik, sehingga terbentuk suatu kebiasaan belajar yang efektif dan mampu meningkatkan prestasi dalam kegiatan belajarnya.

Setiap orang tua memiliki pola pengasuhan yang berbeda-beda. Pola asuh tersebut akan mempengaruhi kebiasaan-kebiasaan anak dalam belajar. Pola pengasuhan yang tepat akan membuat anak memiliki kebiasaan-kebiasaan baik dalam belajar. Kebiasaan belajar yang baik akan mempengaruhi hasil belajar yang dicapai anak. Rahmat (dalam Garliah, 2010) menjelaskan bahwa proses bimbingan yang baik dari orang tau dan pendidik terhadap anak dapat dilakukan dengan cara mengembangkan suasana belajar yang kondusif agar anak dapat mengatasi kesulitan belajar yang dihadapinya sehingga mampu mencapai hasil belajar yang optimal.

Pola asuh orang tua dan kebiasaan belajar merupakan faktor yang mempengaruhi hasil belajar. Wasliman (dalam Susanto, 2013) menyebutkan faktorfaktor yang mempengaruhi hasil beajar terdiri dari faktor internal dan eksternal. 
Faktor internal merupakan faktor yang bersumber dari dalam peserta didik meliputi kecerdasan, minat dan perhatian, motivasi belajar, serta kondisi fisik dan kesehatan.faktor internal merupakan faktor yang bersumber dari luar peserta didik meliputi kelurga, sekolah dan masyarakat. Orang tua yang menerapkan pola pengasuhan yang tepat, oraang tua dan pendidik yang mampu mebentuk kebiasaan belajar baik pada anak tentunya dapat membuat anak mencapai hasil belajar yang memuaskan.

Berdasarkan uraian di atas maka peneliti menyimpulkan bahwa hipotesis diterima artinya ada hubungan yang signifikan dan positif antara persepsi peserta didik tentang pola asuh orang tua dan kebiasaan belajar dengan hasil belajar tema 1 subtema 1 (Indahnya Kebersamaan) peserta didik kelas IV SD Muhammadiyah Metro Pusat. Hubungan ini ditandai dengan koefisien korelasi sebesar 0,436 pada taraf sedang dan sumbangan variabel X1dan X2 terhadap Y sebesar 19,00\% dan $81,00 \%$ dipengaruhi oleh faktor lain seperti faktor internal meliputi kecerdasan, minat, motivasi belajar, ketekunan sikap, serta faktor eksternal meliputi sekolah, keluarga dan masyarakat.

\section{KESIMPULAN}

Berdasarkan hasil penelitian dan pembahasan tentang hubungan persepsi peserta didiktentang pola asuh orang tua dan kebiasaan belajar dengan hasil belajar tema 1 subtema 1 (Indahnya Kebersamaan) peserta didik kelas IV SD Negeri Muhammadiyah Metro Pusat dapat disimpulkan bahwa:

1. Terdapat hubungan yang positif dan signifikan antara persepsi peserta didiktentang pola asuh orang tua dengan hasil belajar tema 1 subtema 1 (Indahnya Kebersamaan) peserta didik kelas IV SD Muhammadiyah Metro Pusat ditunjukkan dengan koefisien korelasi sebesar 0,389 berada pada taraf rendah.

2. Terdapat hubungan yang positif dan signifikan antara kebiasaan belajar dengan hasil belajar tema 1 subtema 1 (Indahnya Kebersamaan) peserta didik kelas IV SD Muhammadiyah Metro ditunjukkan dengan koefisien korelasi sebesar 0,238 berada pada taraf rendah. 
3. Terdapat hubungan yang positif dan signifikan antara persepsi peserta didik tentang pola asuh orang tua dan kebiasaan belajar dengan hasil belajar tema 1 subtema 1 (Indahnya Kebersamaan) peserta didik kelas IV SD Negeri Muhammadiyah Metro Pusat ditunjukkan dengan kofisien kolerasi sebesar 0,436 berada pada taraf sedang.

\section{DAFTAR PUSTAKA}

Aunurrahman. (2013). Belajar dan Pembelajaran. Alfabeta: Bandung.

Garliah, L., \& Nasution, F. K. S. (2005). Peran pola asuh orang tua dalam motivasi berprestasi. Jurnal Psikologia, 1(1), 38-47.

Hidayati, A. K. (2016). Hubungan Kebiasaan Belajar dengan Hasil Belajar Siswa Kelas IV SD Se-Gugus II Piyungan. BASIC EDUCATION, 5(30), 2-895.

Karnangsyah, E. (2017). Hubungan pola asuh orangtua dengan hasil belajar siswa dan implikinya terhadap pelayanan bimbingan dan konseling. Jurnal EDUCATIO: Jurnal Pendidikan Indonesia, 3(1), 1-9.

Magfirah, I. (2015). Pengaruh Kebiasaan Belajar terhadap Prestasi Belajar Matematika Kelas V SD Negeri 2 Bontomantene Kepulauan Selayar. Jurnal Matematika dan Pembelajaran, 3(1).

Oktarina, L. P. (2010). Hubungan antara Pola Asuh Orang Tua dan Motivasi Belajar dengan Prestasi Belajar Matematika Siswa Kelas V SD Negeri 1 Purwantoro. Surakarta: Universitas Sebelas Maret.

Riduwan. (2013). Belajar Mudah Penelitian. Alfabeta: Bandung.

Sagala, Syaiful. 2013. Konsep dan Makna Pembelajaran. Alfabeta: Bandung.

Siagian, R. E. F. (2015). Pengaruh minat dan kebiasaan belajar siswa terhadap prestasi belajar matematika. Formatif: Jurnal Ilmiah Pendidikan MIPA, 2(2).

Spera, C. (2005). A review of the relationship among parenting practices, parenting styles, and adolescent school achievement. Educational psychology review, 17(2), 125-146.

Sudjana, Nana. (2010). Penilaian Hasil Proses Belajar Mengajar. PT. Remaja Rosdakarya: Bandung.

Susanto, Ahmad. (2013). Teori Belajar dan Pembelajaran di Sekolah Dasar. Kencana Prenada Media Group: Jakarta. 